\title{
Interleukin-17 in Systemic Lupus Erythematosus and Rheumatoid Arthritis Patients: Correlation with Clinical Presentation, Laboratory Parameters and Activity Indices
}

\author{
Eman Hassan Elsayed Hassan ${ }^{1}$, Riham Fadl Moftah ${ }^{2}$ \\ ${ }^{1}$ Rheumatology Department, Faculty of Medicine, Alexandria University, Alexandria, Egypt \\ ${ }^{2}$ Clinical Pathology Department, Faculty of Medicine, Alexandria University, Alexandria, Egypt
}

Email address:

emanhassan96@yahoo.com (E. H. E. Hassan)

\section{To cite this article:}

Eman Hassan Elsayed Hassan, Riham Fadl Moftah. Interleukin-17 in Systemic Lupus Erythematosus and Rheumatoid Arthritis Patients: Correlation with Clinical Presentation, Laboratory Parameters and Activity Indices. American Journal of Internal Medicine. Vol. 4, No. 1, 2016, pp. 5-11. doi: 10.11648/j.ajim.20160401.12

\begin{abstract}
Serum interleukin (IL)-17 concentrations have been reported to be increased in systemic lupus erythematosus (SLE), but associations with clinical characteristics are not well understood. Autoimmune diseases such as rheumatoid arthritis (RA), classically believed to be Th1-mediated, are predominantly driven by a Th17 immune response. The aim of the work is to compare the serum levels of IL-17 in patients with SLE and RA, it is correlation with clinical presentations, laboratory findings and disease activity in both diseases. The study was carried out on 3 groups. Group I: 20 patients with SLE. Group II: 20 patients with RA. Group III: 10 of age and sex matched healthy subjects as a control group. In this study, there were no statistical significant differences between the three studied groups regarding disease duration, disease activity, laboratory investigations (except HB, WBC and platelet count). The mean serum level of IL-17 were 173.2 $\pm 52.11,82.6 \pm 48.17$ and $73.07 \pm 41.05$ for group I (SLE), II (RA) and III (Control) respectively, group I has values statistically higher than other groups, and group II has values statistically higher than group III. Serum IL-17 level was significantly higher in SLE patients compared to healthy group. We concluded that, Serum IL-17 concentration correlates with SLE and RA diseases activity but is significantly elevated in patients with SLE disease. The association of other cytokines with serum IL-17 suggests that IL-17 may drive activation of diverse immune pathways in SLE and RA.
\end{abstract}

Keywords: IL-17, SLE, RA

\section{Introduction}

Systemic lupus erythematosus (SLE) is a chronic idiopathic systemic autoimmune disorder characterized by multiple organ damage, particularly the joints, skin, brain and kidneys. [1]

SLE is characterized by both innate and adaptive immune dysregulation, but the relative importance of cytokines operative in these systems is unknown. [2,3]

Rheumatoid arthritis (RA) is a chronic, progressive, inflammatory autoimmune disease associated with articular, extra-articular and systemic effects. It has been reported that RA affects $\sim 0.5-1 \%$ of the adult population of developed regions. [4] Although some patients have mild self-limited disease, many experience joint destruction, severe physical disability and multiple co-morbidities. [5]
Mortality rates are more than twice as high in patients with RA as in the general population. [6]

$\mathrm{T}$ cells, B cells and the orchestrated interaction of proinflammatory cytokines play key roles in the pathophysiology of RA. [7, 8]

The cytokines most directly implicated in this process are TNF- $\alpha$ and IL-6; IL-1 and IL-17 may also play important, albeit arguably less so, roles in the disease process. [7]

Interleukin (IL)-17 is the prototypic T helper 17 (Th17) cell pro-inflammatory cytokine. Since the identification of Th17 cells as a third subset of CD4+ T effector cells, $[2,3]$ there has been much interest regarding the role of the Th17 axis in the pathogenesis of autoimmune disease. IL-17 has been associated with the pathogenesis of a range of autoimmune diseases, including rheumatoid arthritis (RA) [9], systemic sclerosis [10], multiple sclerosis (MS) [11], and SLE [12]. 
Correlations between serum IL-17 levels and SLE disease activity and anti- double stranded DNA (anti-dsDNA) antibody levels have been reported [13, 14]. However the potential relationships between IL-17 and the clinical expression of SLE is lacking. [15]

\section{Aim of the Work}

To compare the serum level of IL-17 in patients with SLE and RA, it's correlation with the clinical presentations, laboratory findings and disease activity in both diseases.

\section{Subject and Methods}

The study was carried out on 3 groups. Patients were enrolled from the outpatient clinic of the Rheumatology unit of the Main University Hospital in Alexandria and from the rheumatology ward of the Main Hospital.

Group I: 20 patients with SLE fulfilling systemic lupus international collaborating clinics (SLICC) 2012 criteria for diagnosis of SLE [16]

Group II: 20 patients with RA fulfilling the American College of Rheumatology/European League Against Rheumatism (ACR/EULAR) 2010 classification criteria of RA. [17]

Group III: 10 of age and sex matched healthy subjects as control group.

\subsection{All Patients Were Subjects to the Following}

1. Clinical study:

I. A detailed history taking and a thorough interrogation of different clinical manifestations of the disease.

II. Complete physical examination with thorough systemic evaluation particularly for:

a In rheumatoid arthritis special emphasis on joint examination for presence of swellings, tenderness or deformities. Also all patients were examined for extra-articular manifestations.

b In systemic lupus erythematosus special emphasis on malar rash, photosensitivity, cardiovascular, respiratory, neurological, renal, hematological affections and vasculitic lesions.

c The patients clinical charts were extensively reviewed to obtain clinical data and to detect the severity of the disease by:

i. SLE Disease activity Index (SLE DAI) score, [18] for lupus patients.

ii. Disease Activity score 28 CRP (DAS 28) [19] High disease activity relates to DAS $28>5.1$, moderate to DAS 28 of 3.2 to 5.1, low disease activity is regarded in the range of 2.6 to 3.2 and remission to DAS $28<2.6$.

2. Laboratory investigations done included:

I. Routine laboratory investigations:

a Complete blood picture. [20]

b Blood urea, serum creatinine c Hepatic enzymes (AST, ALT)

d Complete urine analysis.

e Erythrocyte sedimentation rate (ESR)

f C-reactive protein (CRP) [21]

II. Immunological profile including:

For SLE
a Antinuclear antibody (ANA) [22]
b Anti-double stranded antibodies (anti-DNA)
c Complement C3, C4. [23]

For RA

a Rheumatoid factor titre by Rose Waalar test. [24]

b Anti citrullinated peptide antibody (ACPA)

III. Specific laboratory investigations:

Detection of serum interleukin-17 (IL-17) level using enzyme linked immuno-sorbant assay (ELISA). [25] Sera were obtained and stored at $-20^{\circ} \mathrm{C}$ until the time of use.

\subsection{Statistical Analysis of the Data}

Data were fed to the computer and analyzed using IBM SPSS software package version 20.0. Comparison between different groups regarding categorical variables was tested using Chi-square test. Normally quantitative data was compared using student t-test, or F test (ANOVA), abnormally distributed data was compared using Mann Whitney test or Kruskal Wallis test, Correlations between two quantitative variables were assessed using Pearson or Spearman coefficient according to test of normality. Significance of the obtained results was judged at level of 0.05 .

\section{Results}

The study was carried out on 3 groups. Patients were enrolled from the outpatient clinic of the Rheumatology unit of the Main University Hospital in Alexandria and from the rheumatology ward of the Main Hospital. Group I: 20 patients with SLE fulfilling systemic lupus international collaborating clinics (SLICC) 2012 criteria for diagnosis of SLE. Group II: 20 patients with RA fulfilling the American College of Rheumatology/European League Against Rheumatism (ACR/EULAR) 2010 classification criteria of RA. Group III: 10 of age and sex matched healthy subjects as a control group.

\subsection{Demographic Data}

Table (1) shows demographic data of the studied groups, it demonstrated that:

Age

Age ranged from $22-56,28-58$ and $30-55$ years with the mean of $43.1 \pm 8.98,46.8 \pm 8.17$ and $41.98 \pm 8.25$ for group I (SLE), II (RA) and III (control) respectively, there were no statistical significant differences between the studied groups regarding age. $(\mathrm{P}=0.105)$

Sex

This study include $2(10.0 \%), 3(15.0 \%)$ and $2(20.0 \%)$ males and $18(90.0 \%), 17(85.0 \%)$ and $8(80.0 \%)$ females for 
group I (SLE), II (RA) and III (control) respectively, there were no statistical significant differences between the studied groups regarding sex. $(\mathrm{P}=0.589)$

Disease duration

Disease duration ranged from 3-11 and 2-12 with the mean of $5.11 \pm 6.01$ and $6.01 \pm 3.68$ for group I (SLE) and II (RA) respectively, there were no statistical significant differences between the studied groups regarding disease duration. $(\mathrm{P}=0.152)$.

Table 1. Demographic data of the studied groups.

\begin{tabular}{lllll}
\hline & $\begin{array}{l}\text { Group I } \\
\text { "SLE" } \\
\text { "n=20" }\end{array}$ & $\begin{array}{l}\text { Group II } \\
\text { "RA" } \\
\text { "n=20" }\end{array}$ & $\begin{array}{l}\text { Group III } \\
\text { "control” } \\
\text { "n=10" }\end{array}$ & p \\
\hline $\begin{array}{l}\text { Age } \\
\text { Range }\end{array}$ & $22-56$ & $28-58$ & $30-55$ & 0.105 \\
$\begin{array}{l}\text { Mean } \pm \text { S. D. } \\
\text { Sex }\end{array}$ & $43.1 \pm 8.98$ & $46.6 \pm 8.17$ & $41.98 \pm 8.25$ & \\
$\begin{array}{l}\text { Male } \\
\text { Female }\end{array}$ & $2(10.0 \%$ & $3(15.0)$ & $2(20.0 \%)$ & \\
$\begin{array}{l}\text { Disease } \\
\text { duration }\end{array}$ & $18(90.0 \%)$ & $17(85.0 \%)$ & $8(80.0 \%)$ & 0.589 \\
$\begin{array}{l}\text { Range } \\
\text { Mean } \pm \text { S. D. }\end{array}$ & $3-11 \pm 4.19$ & $6.01 \pm 3.68$ & - & \\
\hline
\end{tabular}

\subsection{Clinical Data}

Table (2) shows clinical data of the two studied patients groups, it illustrated that, for group I, malar rash was found in $13(65.0 \%)$, photosensitivity was found in $12(60.0 \%)$, cardiovascular symptoms in $7(35.0 \%)$, respiratory symptoms in $5(25.0 \%)$, neurological symptoms in $6(30.0 \%)$, renal symptoms in $2(10.0 \%)$, hematological abnormalities in 2 $(10.0 \%)$, for group II, deformities were found in $11(55.0 \%)$, Rheumatoid nodules were found in $2(10.0 \%)$, while swellings were found in $2(10.0 \%)$ and $18(90.0 \%)$, tender joints were found in $1(5.0 \%)$ and $9(45.0 \%)$ for group I and II respectively.

Table 2. Clinical data of the two studied patients group.

\begin{tabular}{lllll}
\hline & \multicolumn{2}{l}{$\begin{array}{l}\text { Group I "SLE" } \\
\text { "n=20" }\end{array}$} & $\begin{array}{l}\text { Group II "RA" } \\
\text { "n=20" }\end{array}$ \\
\cline { 2 - 5 } & No. & $\mathbf{\%}$ & No. & \% \\
\hline $\begin{array}{l}\text { Malar rash } \\
\text { photosensitivity }\end{array}$ & 13 & 65.0 & - & - \\
Cardiovascular & 12 & 60.0 & - & - \\
symptoms & 7 & 35.0 & - & - \\
respiratory symptoms & 5 & 25.0 & - & - \\
neurological & 6 & 30.0 & - & - \\
symptoms & 2 & 10.0 & - & - \\
renal symptoms & 2 & 10.0 & - & - \\
hematological & & - & - & - \\
abnormalities & - & 10.0 & 18 & 90.0 \\
vasculitis symptoms & 2 & 5.0 & 9 & 45.0 \\
$\begin{array}{l}\text { Swellings } \\
\text { Tender joints }\end{array}$ & 1 & - & 11 & 55.0 \\
$\begin{array}{l}\text { Deformities } \\
\text { Rheumatoid Nodules }\end{array}$ & - & - & 2 & 10.0 \\
\hline
\end{tabular}

\subsection{Disease Activity}

Distribution of the studied patients regarding the disease activity were presented in table (3), it showed that, high disease activity was found in $12(60.0 \%)$ and $10(50.0 \%)$, moderate disease activity in $3(15.0 \%)$ and $6(30.0 \%)$, low disease activity in $5(25.0 \%)$ and $4(20.0 \%)$ for group I (SLE), II (RA) respectively, there were no statistical significant differences between the patients groups regarding disease activity. $(\mathrm{P}=0.425)$.

Table 3. Distribution of the studied patients regarding the disease activity.

\begin{tabular}{lllll}
\hline & \multicolumn{2}{l}{$\begin{array}{l}\text { Group I "SLE" } \\
\text { "n=20" "SLEDAI" }\end{array}$} & \multicolumn{2}{l}{$\begin{array}{l}\text { Group II "RA" } \\
\text { "n=20" "DAS-28" }\end{array}$} \\
\cline { 2 - 5 } & No. & \% & No. & \% \\
\hline High & 12 & 60.0 & 10 & 50.0 \\
Moderate & 3 & 15.0 & 6 & 30.0 \\
Low & 5 & 25.0 & 4 & 20.0 \\
p & 0.425 & & & \\
\hline
\end{tabular}

Table 4. Comparison between laboratory investigations in the two patients groups.

\begin{tabular}{|c|c|c|c|}
\hline $\begin{array}{l}\text { Laboratory } \\
\text { investigations }\end{array}$ & $\begin{array}{l}\text { Group I "SLE" } \\
\text { "n=20" }\end{array}$ & $\begin{array}{l}\text { Group II "RA" } \\
\text { "n=20" }\end{array}$ & $\mathbf{P}$ \\
\hline $\mathrm{HB}$ g/dl & & & \\
\hline Range & $8.3-11.4$ & $9.5-12.7$ & \\
\hline $\begin{array}{l}\text { Mean } \pm \text { S. D. } \\
\text { RBCs count }\end{array}$ & $10.32 \pm 1.41$ & $11.41 \pm 1.31$ & $0.041 *$ \\
\hline Range & $4.05-5.9$ & $4.01-5.31$ & \\
\hline $\begin{array}{l}\text { Mean } \pm \text { S. D. } \\
\text { WBCs count }\end{array}$ & $5.01 \pm 0.46$ & $4.92 \pm 0.45$ & 0.298 \\
\hline Range & $2.40-6.5$ & $3.80-9.60$ & \\
\hline $\begin{array}{l}\text { Mean } \pm \text { S. D. } \\
\text { Platelet count }\end{array}$ & $4.92 \pm 1.63$ & $6.91 \pm 3.71$ & $0.0311 *$ \\
\hline Range & $25.000-340.000$ & $166.00-530.00$ & \\
\hline $\begin{array}{l}\text { Mean } \pm \text { S. D. } \\
\text { ALT }\end{array}$ & $270.0 \pm 122.71$ & $336.1 \pm 89.6$ & $0.039 *$ \\
\hline Range & $13.0-55.0$ & $15.00-43.0$ & \\
\hline $\begin{array}{l}\text { Mean } \pm \text { S. D. } \\
\text { AST }\end{array}$ & $35.11 \pm 19.86$ & $38.00 \pm 11.66$ & 0.125 \\
\hline Range & $25.0-40.0$ & $21.0-33.0$ & \\
\hline $\begin{array}{l}\text { Mean } \pm \text { S. D. } \\
\text { Blood urea }\end{array}$ & $36.11 \pm 10.64$ & $28.74 \pm 5.12$ & 0.366 \\
\hline Range & $22-45$ & $24-51$ & \\
\hline $\begin{array}{l}\text { Mean } \pm \text { S. D. } \\
\text { Serum creatinine }\end{array}$ & $36.9 \pm 6.21$ & $39.8 \pm 8.32$ & 0.107 \\
\hline Range & $0.61-1.3$ & $0.55-1.41$ & \\
\hline $\begin{array}{l}\text { Mean } \pm \text { S. D. } \\
\text { ESR (mm) }\end{array}$ & $0.89 \pm 0.42$ & $0.79 \pm 0.55$ & 0.233 \\
\hline Range & $30-140$ & $25-115$ & \\
\hline $\begin{array}{l}\text { Mean } \pm \text { S. D. } \\
\text { CRP (mg/dl) }\end{array}$ & $72.0 \pm 35.8$ & $74.2 \pm 30.6$ & 0.884 \\
\hline Negative & $16(80 \%)$ & $0(0.0 \%)$ & \\
\hline Positive & $4(20 \%)$ & $20(100 \%)$ & $0.000 *$ \\
\hline
\end{tabular}

\subsection{Laboratory Investigations}

Distribution of the studied patients regarding the laboratory investigations were presented in table (4), it showed that,

$H g(g / d l)$

It ranged from 8.3-11.4 and 9.5-12.7 with the mean of $10.32 \pm 1.41$ and $11.41 \pm 1.31$ for group I (SLE) and II (RA) respectively, group II has values statistically higher than group I. ( $\mathrm{P}=0.041)$.

RBCs count 
It ranged from 4.05-5.9 and 4.01-5.31 with the mean of $5.01 \pm 0.46$ and $4.92 \pm 0.45$ for group I (SLE) and II (RA) respectively, group I has values statistically higher than group II. ( $\mathrm{P}=0.298)$.

\section{WBCs count}

It ranged from 2.40-6.5 and 3.80-9.60 with the mean of $4.92 \pm 1.63$ and $6.91 \pm 3.71$ for group I (SLE) and II (RA) respectively, group II has values statistically higher than group I. ( $\mathrm{P}=0.0311)$.

\section{Platelet count}

It ranged from 25.0000-340.000 and 166.00-530.00 with the mean of $270.0 \pm 122.71$ and $336.1 \pm 89.6$ for group I (SLE) and II (RA) respectively, group II has values statistically higher than group I. $(\mathrm{P}=0.039)$.

\section{$C R P$}

Negative CRP was found in $16(80 \%)$ and $0(0.0 \%)$, while positive CRP was found in $4(20 \%)$ and $20(100.0 \%)$ for group I (SLE) and II (RA).

There were no statistical significant differences between the two studied groups regarding ALT, AST, blood urea and serum creatinine and ESR.

Table 5. Immunological profile for the two studied patients group.

\begin{tabular}{|c|c|c|c|}
\hline $\begin{array}{l}\text { Immunological } \\
\text { investigation }\end{array}$ & $\begin{array}{l}\text { Group I "SLE" } \\
\text { "n=20" }\end{array}$ & $\begin{array}{l}\text { Group II "RA" } \\
\text { "n=20" }\end{array}$ & $\mathbf{P}$ \\
\hline ANA & & & \\
\hline Range & $40-640$ & $20-320$ & \\
\hline $\begin{array}{l}\text { Mean } \pm \text { S. D. } \\
\text { Anti-DNA }\end{array}$ & $266.5 \pm 86.5$ & $165.6 \pm 65.2$ & $0.001 *$ \\
\hline Range & $30-275$ & - & \\
\hline $\begin{array}{l}\text { Mean } \pm \text { S. D. } \\
\text { C3 }\end{array}$ & $125.6 \pm 62.5$ & - & \\
\hline Range & $0.74-1.47$ & $0.84-1.54$ & \\
\hline $\begin{array}{l}\text { Mean } \pm \text { S. D. } \\
\text { C4 }\end{array}$ & $1.1 \pm 0.2$ & $1.2 \pm 0.2$ & 0.301 \\
\hline Range & $0.09-0.26$ & $0.12-0.23$ & \\
\hline $\begin{array}{l}\text { Mean } \pm \text { S. D. } \\
\text { Anti CCP }\end{array}$ & $0.2 \pm 0.04$ & $0.2 \pm 0.03$ & 0.771 \\
\hline -ve & 20 & 7 & \\
\hline$+\mathrm{ve}$ & 0 & 13 & \\
\hline RF & & & \\
\hline -ve & 20 & 14 & \\
\hline$+\mathrm{ve}$ & 0 & 6 & \\
\hline
\end{tabular}

\subsection{Immunological Profile}

Table (5) shows immunological profile of the two studied patients groups; it demonstrated that, distribution of the studied patients regarding the laboratory investigations were presented in table (4), it showed that:

$A N A$

It ranged from 40-640 and 20-320 with the mean of $266.5 \pm 86.5$ and $165.6 \pm 65.2$ for group I (SLE) and II (RA) respectively, group I has values statistically higher than group II. $(\mathrm{P}=0.001)$.

Anti-DNA

It ranged from $30-275$ with the mean of $125.6 \pm 62.5$ for group I (SLE) only.

C3

It ranged from $0.74-1.47$ and $0.84-1.54$ with the mean of $1.1 \pm 0.2$ and $1.2 \pm 0.2$ for group I (SLE) and II (RA) respectively; there were no statistical significant differences between the two studied groups. $(\mathrm{P}=0.301)$.

C4

It ranged from $0.09-0.26$ and $0.12-0.23$ with the mean of $0.2 \pm 0.04$ and $0.2 \pm 0.03$ for group I (SLE) and II (RA) respectively; there were no statistical significant differences between the two studied groups. $(\mathrm{P}=0.771)$.

Anti CCP

Negative Anti CCP was found in all patients for group I (SLE) and 7 for group II, while positive Anti CCP was found in 13 patients for group II (RA).

$R F$

Negative RF was found in all patients of group I (SLE) and 14 patients of group II (RA), while positive RF was found in only 6 patients of group II (RA).

IL-17

Table (6) shows the serum level of IL-17 in the studied groups, it illustrated that, IL-17 ranged from 52-340, 41-251 and 40-108 with the mean of $173.2 \pm 52.11,82.6 \pm 48.17$ and $73.07 \pm 41.05$ for group I (SLE), II (RA) and III (Control) respectively, group I has statistically higher values than the other two groups, and group II has statistically higher values than group III. $(\mathrm{P}=0.013)$.

Table 6. IL-17 in different studied groups.

\begin{tabular}{llll}
\hline & $\begin{array}{l}\text { Group I "SLE” } \\
\text { “n=20" }\end{array}$ & $\begin{array}{l}\text { Group II "RA" } \\
\text { "n= 20" }\end{array}$ & $\begin{array}{l}\text { Group III } \\
\text { "control" "n=10" }\end{array}$ \\
\hline IL-17 & & & \\
Range & $52-340$ & $41-251$ & $40-108$ \\
Mean \pm S. D. & $173.2 \pm 52.11$ & $82.6 \pm 48.17$ & $73.07 \pm 41.05$ \\
p & $0.013 *$ & & \\
\hline
\end{tabular}

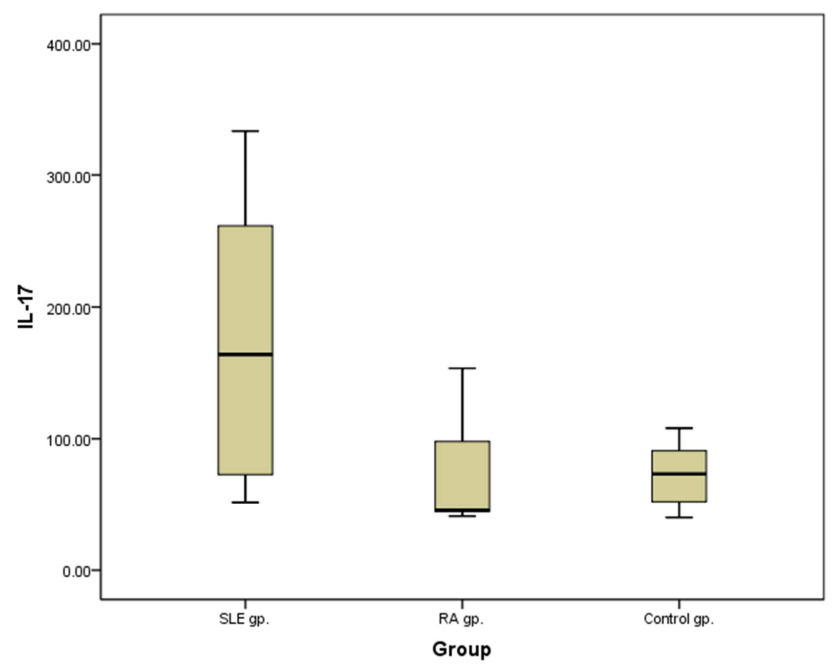

Figure 1. Box-plot illustrated the serum IL-17 levels observed in the three groups included in this study.

\subsection{Correlation}

Table (7) shows correlation between IL-17 and immunological profile and disease duration and disease activity in the group I and group II, it demonstrated that:

There was positive significant correlation between IL-17 with ANA for group I and II, 
There was positive significant correlation between IL-17 with disease activity for both groups I and II.

Table 7. Correlation between IL-17 and immunological profile and disease duration and disease activity in the two patients group.

\begin{tabular}{lllll}
\hline IL-17\# & \multicolumn{2}{l}{$\begin{array}{l}\text { Group I "SLE" } \\
\text { "n=20" }\end{array}$} & \multicolumn{2}{l}{$\begin{array}{l}\text { Group II “RA" } \\
\text { "n=20" }\end{array}$} \\
\hline & $\mathbf{r}$ & $\mathbf{p}$ & $\mathbf{r}$ & $\mathbf{p}$ \\
\hline ANA & 0.442 & $0.0021^{*}$ & 0.405 & $0.008^{*}$ \\
Anti-DNA & 0.398 & 0.013 & - & - \\
C3 & 0.109 & 0.217 & 0.12 & 0.311 \\
C4 & 0.183 & 0.177 & 0.19 & 0.235 \\
Disease duration & 0.425 & 0.005 & 0.246 & 0.079 \\
Disease activity & 0.66 & $0.001 *$ & 0.42 & $0.007 *$ \\
\hline
\end{tabular}

\subsection{Relations}

Relation between disease activity and IL-17 level was presented in table (8), it showed that, Regarding group I (SLE), the mean of IL-17 was $192.0 \pm 46.2,170.3 \pm 36.2$ and $160.3 \pm 48.2$ for high, moderate and low disease activity, with statistical significant differences. ( $\mathrm{P}=0.013$ )

Regarding group II (RA), the mean of IL-17 was
$102.3 \pm 1.0,82.6 \pm 39.5$ and $67.8 \pm 41.0$ for high, moderate and low disease activity, with statistical significant differences. $(\mathrm{P}=0.022)$.

Table 8. Relation between disease activity and IL-17 level.

\begin{tabular}{lll}
\hline & $\begin{array}{l}\text { Group I "SLE" } \\
\text { "n=20" "SLEDAI" }\end{array}$ & $\begin{array}{l}\text { Group II "RA" } \\
\text { "n=20" "DAS-28" }\end{array}$ \\
\hline High & $192.0 \pm 46.2$ & $102.3 \pm 1$ \\
Moderate & $170.3 \pm 36.2$ & $82.6 \pm 39.5$ \\
Low & $160.3 \pm 48.2$ & $67.8 \pm 41.0$ \\
p & $0.013 *$ & $0.022 *$ \\
\hline
\end{tabular}

Relation between clinical data and IL-17 level was presented in table (9), it showed that,

Regarding group I (SLE), there was statistical significant relation between malar rash, photosensitivity, cardiovascular symptoms, hematological symptoms, swellings and tenderness with the high level of serum IL-17.

Regarding group II (RA), there was statistical significant relation between the presence of swellings and tenderness with the high level of serum IL-17.

Table 9. Relation between clinical data and IL-17 level.

\begin{tabular}{|c|c|c|c|c|c|c|}
\hline & \multicolumn{2}{|c|}{ Group I "SLE" "n=20" } & \multirow{2}{*}{$\mathbf{P}$} & \multicolumn{2}{|c|}{ Group II "RA"“n=20" } & \multirow{2}{*}{$\mathbf{p}$} \\
\hline & Present & Absent & & Present & Absent & \\
\hline Malar rash & $198.3 \pm 50.2$ & $168.3 \pm 42.3$ & $0.021 *$ & - & - & \\
\hline photosensitivity & $189.2 \pm 47.5$ & $162.3 \pm 40.3$ & $0.036^{*}$ & - & - & \\
\hline Cardiovascular symptoms & $197.5 \pm 45.6$ & $160.3 \pm 38.2$ & $0.041 *$ & - & - & \\
\hline respiratory symptoms & $178.3 \pm 41.6$ & $170.3 \pm 38.2$ & 0.685 & - & - & \\
\hline neurological symptoms & $179.5 \pm 45.2$ & $169.5 \pm 46.2$ & 0.71 & - & - & \\
\hline hematological symptoms & $199.2 \pm 45.6$ & $160.3 \pm 48.2$ & $0.012 *$ & - & - & \\
\hline vasculitis symptoms & - & - & & - & - & \\
\hline Swellings & $204.3 \pm 4.98$ & $152.3 \pm 57.2$ & $0.002 *$ & $98.6 \pm 36.6$ & $74.2 \pm 35.2$ & $0.013^{*}$ \\
\hline Tenderness & $189.6 \pm 47.2$ & $160.2 \pm 45.2$ & $0.004 *$ & $90.2 \pm 42.6$ & $77.9 \pm 41.8$ & $0.021 *$ \\
\hline Deformities & - & - & & $84.3 \pm 41.3$ & $80.9 \pm 39.5$ & 0.365 \\
\hline Rh. Nodules & - & - & & $86.2 \pm 38.7$ & $79.1 \pm 39.8$ & 0.175 \\
\hline
\end{tabular}

\section{Discussion}

Serum interleukin (IL)-17 concentrations have been reported to be increased in systemic lupus erythematosus (SLE), but associations with clinical characteristics are not well understood. [26]

Autoimmune diseases such as RA, classically believed to be Th1-mediated, are predominantly driven by a Th17 immune response. IL-17 (IL-17A, IL-17F, IL-21, IL-22). This results in augmented infiltration of leukocytes, in particular neutrophils to the affected tissue where they induce organ inflammation and injury. [27]

Our study showed that, there were no statistical significant differences between the three studied groups regarding sex, disease duration, disease activity, laboratory investigations (except for HB, WBC and platelet count).

In agreement with our study, Daman, et al., (2014) demonstrated that, $\mathrm{HB}$, and platelet count were statistically higher in RA than SLE. [28]
In this study, there were statistical significant differences between the patients studied groups regarding ANA, AntiDNA, C3 and C4, SLE group has values statistically higher than RA group.

Jacobs, et al., (2001) demonstrated that, systemic lupus erythematosus patients have values of ANA, C3 and C4 higher than rheumatoid arthritis patients. [29]

In this study, the mean of IL-17 was $173.2 \pm 52.11$, $82.6 \pm 48.17$ and $73.07 \pm 41.05$ for group I (SLE), II (RA) and III (Control) respectively, group I has values statistically higher than other groups, and group II has values statistically higher than group III. Serum IL-17 levels were significantly higher in SLE patients compared to healthy donors.

Fabien, et al., (2013) [26] showed that, the role of IL-17 in the pathogenesis of autoimmune diseases is now well accepted, and as such, IL-17 is a potential therapeutic target. In our study, we reported that serum IL-17 levels were significantly elevated in the serum of SLE patients compared to healthy controls, Fabien, et al., (2013) observed that SLEDAI-2k was positively correlated with IL-17. Serum IL- 
17 was significantly increased in SLE patients. and this relationship was observed regardless of disease activity and persisted when integrating cytokine levels over the period observed. [26]

Conversely, other studies showed no correlation in any patient subset. The reason for these discrepancies is unknown, but may be partially attributable to the relatively small sample sizes used in some studies. [30,31]

In the study on Egyptian RA patients, even though IL-17 serum level did not correlate with the DAS28 score yet it was significantly higher among severely active patients as compared to patients with moderate activity. [32]

In our study, regarding group I (SLE), the mean of IL-17 was $192.0 \pm 46.2, \quad 170.3 \pm 36.2$ and $160.3 \pm 48.2$ for high, moderate and low disease activity, with statistical significant differences. Regarding group II (RA), the mean of IL-17 was $102.3 \pm 1.0,82.6 \pm 39.5$ and $67.8 \pm 41.0$ for high, moderate and low disease activity, with statistical significant differences.

This is in agreement with the results of Metawi et al.(2011) [33], who reported that there was a direct relation between the serum level of IL-17 and disease activity and severity in RA patients.

Also, Sarkar et al. (2014) [34] found that IL-17A increases during inflammatory arthritis and that neutralization of IL-17A reduces the severity of arthritis. Moreover, significantly higher levels of IL-17A were detected in the peripheral blood of patients with rheumatoid.

This is commensurate with the results of Kim et al. (2013) [35], who suggest that IL-17 play an important role in RA pathogenesis, and that the level of IL-17A in the peripheral blood is associated with increased disease activity and articular destructive effects, and effusion in RA patients.

Pavlovic et al. (2014) [36] found that the mean serum IL$17 \mathrm{~A}$ levels in patients with early RA corresponded with disease activity and severity. This might highlight the usefulness of the serum IL-17A level in defining the activity and predictive patterns, to aid in aggressive disease therapy, and it might express specific therapeutic targets.

An association between RA and systemic lupus erythematosus (SLE) has been suggested. Similar to RA, IL17 is elevated in the serum of patients with SLE compared to patients without SLE. [37]

\section{Conclusions}

Serum IL-17 concentration correlates with SLE and RA diseases activity but is significantly elevated in patients with SLE disease. The association of other cytokines with serum IL-17 suggests that IL-17 may drive activation of diverse immune pathways in SLE and RA. Our data raised the hope to use IL-17 as crucial biomarker and therapeutic target in autoimmune diseases specially SLE and RA.

However the limitation of our study was the small sample size, so we recommend further studies to be conducted over larger number of patients with special emphasis on the factors that may influence the serum level of IL-17 like infections other co-morbidities and the effect of some medications especially biological therapies and Immunosuppressant drugs which have an impact on serum IL-17 concentrations, and thereby may by a confounding factor when analyzing correlation between serum cytokines and disease activity.

\section{References}

[1] Tsokos GC: Systemic lupus erythematosus. N Engl J Med 2011, 365: 2110-2121.

[2] Park H, Li Z, Yang XO, Chang SH, Nurieva R, Wang YH, Wang Y, Hood L, Zhu Z, Tian Q, Dong C: A distinct lineage of CD4 $\mathrm{T}$ cells regulates tissue inflammation by producing interleukin 17. Nat Immunol 2005, 6: 1133-1141.

[3] Harrington LE, Hatton RD, Mangan PR, Turner H, Murphy TL, Murphy KM, Weaver CT: Interleukin 17-producing CD4+ effector $\mathrm{T}$ cells develop via a lineage distinct from the T helper type 1 and 2 lineages. Nat Immunol. 2005, 6: 1123-1132.

[4] Carbonell J, Cobo T, Balsa A, Descalzo MA, Carmona L. The incidence of rheumatoid arthritis in Spain: results from a nationwide primary care registry. Rheumatology 2008; 47: 1088-92.

[5] Plenge RM. Rheumatoid arthritis genetics: 2009 update. Curr Rheumatol Rep 2009; 11: 351-6.

[6] Gonzalez A, Maradit KH, Crowson CS, et al. The widening mortality gap between rheumatoid arthritis patients and the general population. Arthritis Rheum 2007; 56: 3583-7

[7] Smolen JS, Steiner G. Therapeutic strategies for rheumatoid arthritis. Nat Rev Drug Discov 2003; 2: 473-88.

[8] Smolen JS, Aletaha D, Koeller M, Weisman MH, Emery P. New therapies for treatment of rheumatoid arthritis. Lancet 2007; 370: 1861-74.

[9] Chabaud M, Durand JM, Buchs N, Fossiez F, Page G, Frappart L, Miossec P: Human interleukin-17: A T cellderived proinflammatory cytokine produced by the rheumatoid synovium. Arthritis Rheum 1999, 42: 963-970.

[10] Kurasawa K, Hirose K, Sano H, Endo H, Shinkai H, Nawata Y, Takabayashi K, Iwamoto I: Increased interleukin-17 production in patients with systemic sclerosis. Arthritis Rheum 2000, 43: 2455-2463.

[11] Lock C, Hermans G, Pedotti R, Brendolan A, Schadt E, Garren H, Langer-Gould A, Strober S, Cannella B, Allard J, Klonowski P, Austin A, Lad N, Kaminski N, Galli SJ, Oksenberg JR, Raine CS, Heller R, Steinman L: Genemicroarray analysis of multiple sclerosis lesions yields new targets validated in autoimmune encephalomyelitis. Nat Med 2002, 8: 500-508.

[12] Nalbandian A, Crispin JC, Tsokos GC: Interleukin-17 and systemic lupus erythematosus: current concepts. Clin Exp Immunol 2009, 157: 209-215.

[13] Wong CK, Lit LC, Tam LS, Li EK, Wong PT, Lam CW: Hyperproduction of IL-23 and IL-17 in patients with systemic lupus erythematosus: implications for Th17-mediated inflammation in auto-immunity. Clin Immunol 2008; 127: 385-393. 
[14] Doreau A, Belot A, Bastid J, Riche B, Trescol-Biemont MC, Ranchin B, Fabien N, Cochat P, Pouteil-Noble C, Trolliet P, Durieu I, Tebib J, Kassai B, Ansieau S, Puisieux A, Eliaou JF, Bonnefoy-Berard N: Interleukin 17 acts in synergy with $\mathrm{B}$ cell-activating factor to influence $\mathrm{B}$ cell biology and the pathophysiology of systemic lupus erythematosus. Nat Immunol 2009; 10: 778-785.

[15] Chun HY, Chung JW, Kim HA, Yun JM, Jeon JY, Ye YM, Kim SH, Park HS, Suh CH: Cytokine IL-6 and IL-10 as biomarkers in systemic lupus erythematosus. J Clin Immunol 2007, 27: 461-466.

[16] Michelle Petri, Ana-Maria Orbai, Graciela S. Alarcón, Caroline Gordon, Joan T. Merrill, Paul R. Fortin, et al. Derivation and Validation of Systemic Lupus International Collaborating Clinics Classification Criteria for Systemic Lupus Erythematosus. Arthritis Rheum. 2012; 64(8): 26772686.

[17] Aletaha D, Neogi T, Silman AJ, et al., 2010 Rheumatoid arthritis classification criteria: an American college of Rheumatology/European League Against Rheumatism collaborative initiative. Arthritis Rheum. 2010; 62: 41: 1571.

[18] Isenberg DA, Rahman A, Allen E. Disease activity index for patients with SLE. Rheum 2005; 44: 902-6.

[19] 100. Fransen JI, van Riel PL. The Disease Activity score and the EULAR response criteria. Rheum Dis Clin North Am. 2009; 35(4): 745-57.

[20] Dalie JV, Lwis SD. Basic haematological technique in practical hematology. 7th edition. Edinburgh, London: Churchill Livingstone; 1994. 5: 37-66.

[21] Ritche DF, Boyle JA, Innes JM. Clinical studies with an articular index for assessment of joint tenderness in patient with rheumatoid arthritis. QJ Med 1988; 37: 393-406.

[22] Sinico RA, Bollini B, Sabadini E, Di Toma L, Raice A. the use of laboratory tests in diagnosis and monitoring of systems lupus erythematosus. J Nephrol 2002; 15(6): 20-7.

[23] Maneini G, Caronora AO, Herman JF. Immunochemical quantitation of antigen by single radial immune diffusion. Immunochemistry $1965 ; 2: 253-7$.

[24] Rose HH, Rogan B, Peass E. Differential agglutination of normal sensitized sheep erythrocyte sera of patients with rheumatoid arthritis. Pro Soc Exp Biol. 1980; 68: 1-5.

[25] Numasaki M., J. Fukushi, M. Ono, S. K. Narula, P. J. Zavodny, T. Kudo, et al. Interleukin-17 promotes angiogenesis and tumor growth. Blood, 101 (7) (2003), pp. 2620-2627.

[26] Fabien BV, Melissa N, Alberta H, Fabienne M and Eric FM. Clinical association of serum interleukin-17 in systemic lupus erythematosus. Arthritis research and therapy. 2013; 15: 1-9.
[27] Chabaud M, F. Fossiez, J. L. Taupin, P. Miossec. Enhancing effect of IL-17 on IL-1-induced IL-6 and leukemia inhibitory factor production by rheumatoid arthritis synoviocytes and its regulation by Th2 cytokines. J Immunol, 161 (1998), pp. 409414.

[28] Daman L. laboratory investigation of rhematic and connective tissue disease. Sullivan Nicolaides pathology. 2014.

[29] Jacobs R, Pawlak CR, Mikeska E, Meyer Olson D, Martin M, Heijnen J, Schedlowski M, Schmidt RE. Systemic lupus erythematosus and rheumatoid arthritis patinets differ from healthy controls in their cytokine pattern after stress exposure. Rheumatology. 2001; 40: 868-875.

[30] Cheng F, Guo Z, Xu H, Yan D, Li Q: Decreased plasma IL22 levels, but not increased IL17 and IL23 levels, correlate with disease activity in patients with systemic lupus erythematosus. Ann Rheum Dis 2009, 68: 604-606.

[31] Zhao XF, Pan HF, Yuan H, Zhang WH, Li XP, Wang GH, Wu GC, Su H, Pan FM, Li WX, Li LH, Chen GP, Ye DQ: Increased serum interleukin 17 in patients with systemic lupus erythematosus. Mol Biol Rep 2010; 37: 81-85.

[32] Kotake S., N. Udagawa, N. Takahashi, K. Matsuzaki, K. Itoh, S. Ishiyama, et al. IL-17 in synovial fluids from patients with rheumatoid arthritis is a potent stimulator of osteoclastogenesis. J Clin Invest. 1999; 103: pp. 1345-1352

[33] Metawi SA, Abbas D, Kamal MM, Ibrahim MK. Serum and synovial fluid levels of interleukin-17 in correlation with disease activity in patients with RA. Clin Rheumatol 2011; 30: 1201-1207.

[34] Sarkar S, Justa S, Brucks M, Endres J, Fox DA, Zhou X, et al. Interleukin (IL)-17A, F and AF in inflammation: a study in collagen-induced arthritis and rheumatoid arthritis. Clin Exp Immunol 2014; 177: 652-661.

[35] Kim J, Kang S, Kim J, Kwon G, Koo S. Elevated levels of T helper 17 cells are associated with disease activity in patients with rheumatoid arthritis. Ann Lab Med 2013; 33: 52-59.

[36] Pavlovic V, Dimic A, Milenkovic S, Krtinic D. Serum levels of IL-17, IL-4, and INFy in Serbian patients with early rheumatoid arthritis. J Res Med Sci 2014; 19: 18-22.

[37] Doreau A., A. Belot, J. Bastid, B. Riche, M. C. TrescolBiemont, B. Ranchin, N. Fabien, P. Cochat, C. Pouteil-Noble, P. Trolliet, I. Durieu, J. Tebib, B. Kassai, S. Ansieau, A. Puisieux, J. F. Eliaou, N. Bonnefoy-Berard Interleukin 17 acts in synergy with B cell-activating factor to influence B cell biology and the pathophysiology of systemic lupus erythematosus. Nat. Immunol., 2009; 10: pp. 778-785. 